\title{
SIMULASI POLA ALIRAN FLUIDA DALAM DAERAH DENGAN BATAS TIDAK TERATUR MENGGUNAKAN METODE ELEMEN HINGGA
}

\author{
Defrianto*, Dwi Putri Cahya Safitri \\ Jurusan Fisika FMIPA Universitas Riau \\ Kampus Bina Widya Pekanbaru, 28293, Indonesia \\ *E-mail korespondensi: defrianto@lecturer.unri.ac.id
}

\begin{abstract}
Research of ideal fluid flow on irregular domain by variation mesh has been done. Laplace equation was used to model velocity potential and the gradient was used to velocity. Boundary condition for inlet was chosen to be 15 $\mathrm{m}^{2} \mathrm{~s}^{-1}$, while for outlet was $30 \mathrm{~m}^{2} \mathrm{~s}^{-1}$ and Neumann boundary condition on lateral side. The developed model shows that uniform flow was happened on straight channel and free vortex on the curved one. The analytical and computational calculation has similar results, that is $23.7787 \mathrm{~m}^{2} \mathrm{~s}^{-1}$ and $23.7792 \mathrm{~m}^{2} \mathrm{~s}^{-1}$. The percentage of the difference is $2.8 \times 10^{-3}$ wich is very small, therefore this method is accurate enough to model pattern of ideal fluid flow on irregular domain.
\end{abstract}

Keywords: Finite element method, irregular domain, ideal fluid, simulation

\begin{abstract}
ABSTRAK
Telah dilakukan penelitian pola aliran fluida ideal pada tidak teratur dengan variasi mesh. Persamaan Laplace digunakan untuk memodelkan potensial kecepatan yang kemudian selanjutnya ditentukan gradiennya untuk memodelkan kecepatan fluida. Kondisi batas inlet sebesar $15 \mathrm{~m}^{2} \mathrm{~s}^{-1}$, bagian outlet $30 \mathrm{~m}^{2} \mathrm{~s}^{-1}$ dan kondisi batas Neumann pada sisi lateral domain. Hasil pemodelan menunjukkan terjadi aliran seragam pada bagian saluran lurus dan vorteks bebas pada bagian kelengkungan. Hasil perhitungan analitis dan komputasi memiliki nilai yang hampir sama yaitu $23.7787 \mathrm{~m}^{2} \mathrm{~s}^{-1}$ dan $23.7792 \mathrm{~m}^{2} \mathrm{~s}^{-1}$. Persentase sangat kecil yaitu $2.8 \times 10^{-3}$ sehingga metode ini baik digunakan pada pemodelan fluida ideal domain tidak teratur.
\end{abstract}

Kata kunci: Metode elemen hingga, domain tidak teratur, aliran irotasional, simulasi

\section{PENDAHULUAN}

Aliran fluida di alam biasanya memiliki pola aliran bervariasi yang disebabkan oleh beberapa faktor, salah satunya adalah bentuk saluran yang tidak teratur seperti pada sungai. Sungai dengan saluran lurus cenderung memiliki pola aliran seragam sementara pada bagian lengkungan lebih kompleks.

Bentuk domain mempengaruhi distribusi kecepatan. Pada kasus yang lebih sederhana seperti aliran fluida yang mengalir pada pipa dengan luas penampang yang berubah, kecepatan berbanding terbalik terhadap luas penampang dan dinyatakan dalam persamaan kontuinitas. Sementara pada saluran melengkung, terjadi ketidakseragaman distribusi kecepatan pada bagian lateral dimana kecepatan tertinggi terjadi pada bagian dalam lengkungan sementara kecepatan terendah terjadi pada bagian luar lengkungan [1].

Fluida memiliki sifat acak, sehingga perlu dilakukan beberapa penyederhanaan seperti mengabaikan tegangan viskositas dan menganggap aliran adalah irotasional, tunak dan tak mampu mampat. Pendekatan ini masih relevan untuk fluida dengan viskositas rendah dan tak mampu-mampat seperti pada air.

Persamaan fluida ideal mengarah pada penyelesaian persamaan Laplace sebagai nilai potensial kecepatan. Jika potensial kecepatan telah ditetapkan, maka kecepatan pada titik- 
titik tertentu dapat diketahui dengan menentukan gradien potensial [2].

Persamaan aliran fluida biasanya terdiri dari persamaan differensial parsial yang rumit sehingga tidak memiliki solusi eksak namun penggunaan metode komputasi dapat digunakan untuk menyelesaikan persamaan tersebut dengan lebih cepat dan akurat. Salah satu metode komputasi yang dapat digunakan adalah metode elemen hingga yaitu metode pemecahan persamaan differensial dengan membagi domain menjadi elemen yang lebih kecil [3] Bentuk dan ukuran dari mesh turut mempengaruhi hasil dari interpolasi seperti semakin kecil ukuran elemen semakin akurat taksiran yang didapat namun dengan konsekuensi dibutuhkan waktu yang lebih lama untuk memprosesnya serta kekonvergenan. Ukuran mesh yang tepat diharapkan memberikan hasil yang optimum [4].

\section{TINJAUAN PUSTAKA}

\section{Pola Aliran}

Pola aliran fluida dapat didefinisikan sebagai suatu visualisasi bentuk kreatif aliran untuk menggambarkan kajian aliran secara kuantitatif maupun kualitatif [5]. Pola aliran adalah komponen penting dalam menganalisa gejala aliran fluida di alam seperti arah, kekuatan, dan variasi aliran berdasarkan waktu.

\section{Persamaan Aliran Fluida Ideal}

Persamaan aliran fluida ideal adalah penyederhanaan dari persamaan Euler. Persamaan Euler sendiri berasal dari ide persamaan Navier-Stokes. Persamaan NavierStokes dinyatakan secara ringkas dalam notasi vektor sebagai berikut:

$$
\rho\left(\frac{\partial}{\partial}+v \cdot \nabla v\right)=-\nabla \mu+\mu \nabla^{2} v
$$

fluida adalah viskos tak-mampu mampat (incompressible viscous) persamaan menjadi,

$$
\frac{\partial}{d}+v \cdot \nabla v=\mu \nabla^{2} v
$$

apabila nilai viskositas dianggap sangat kecil sekali persamaan berubah menjadi,

$$
\frac{\partial}{\partial}+v \cdot \nabla v=0
$$

aliran adalah tunak atau tidak bergantung pada waktu,

$$
v \cdot \nabla v=0
$$

hubungan potensial kecepatan dengan

kecepatan adalah,

$$
v=\nabla \varphi
$$

persamaan aliran fluida menjadi

$$
\nabla^{2} \varphi=0
$$

Persamaan 6 disebut juga sebagai

persamaan Laplace.

\section{Metode Elemen Hingga}

Metode elemen hingga adalah metode numerik untuk mendapatkan solusi persamaan differensial, baik persamaan differensial biasa (Ordinary Differential Equation) maupun persamaan differensial biasa (Partial Differential Equation).

Inti dari metode ini adalah membagi problem yang kompleks (domain) menjadi bagian-bagian kecil atau elemen (diskretisasi) sehingga didapat solusi yang lebih sederhana oleh fungsi interpolasi. Keseluruhan solusi elemen tersebut akan menjadi solusi dari problem [3].

Pada prinsipnya metode elemen hingga terdiri dari tahap-tahap berikut:

1. Diskretisasi domain.

2. Memilih fungsi Interpolasi.

3. Menurunkan elemen matriks dan vektor.

4. Mencari sistem persamaan global.

5. Menyelesaikan persamaan global.

\section{METODE PENELITIAN}

Penelitian ini terdiri dari 7 tahapan yang digambarkan dengan diagram alir penelitian pada Gambar 1. Tahap pertama yang dilakukan adalah mendesain model fisis domain seperti bentuk, ukuran dan kondisi batas domain. Selanjutnya adalah menyusun persamaan matematis yang digunakan. 
Domain yang dibuat dalam penelitian ini adalah domain tidak teratur dan domain juring. Domain juring digunakan untuk menguji error dengan membandingkan hasil analitik dan komputasi. Apabila nilai error dapat diterima maka dilanjutkan dengan perbandingan pengaruh dari ukuran mesh untuk domain juring. Langkah selanjutnya adalah menjalankan program untuk domain tidak teratur. Model yang ditampilkan nantinya akan dianalisa dan ditarik kesimpulan dari hasil analisa.

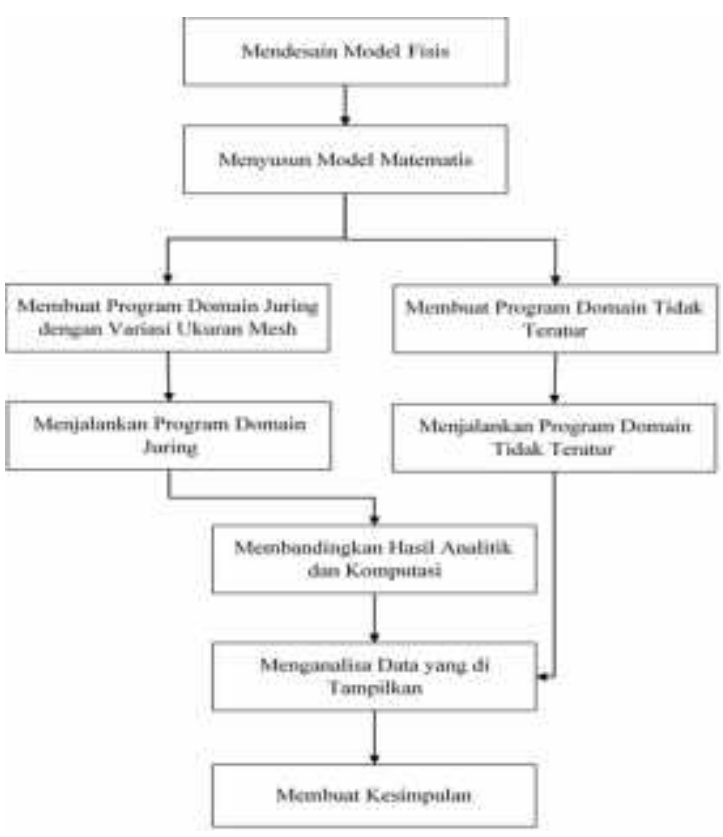

Gambar 1. Diagram alir penelitian

\section{HASIL DAN PEMBAHASAN}

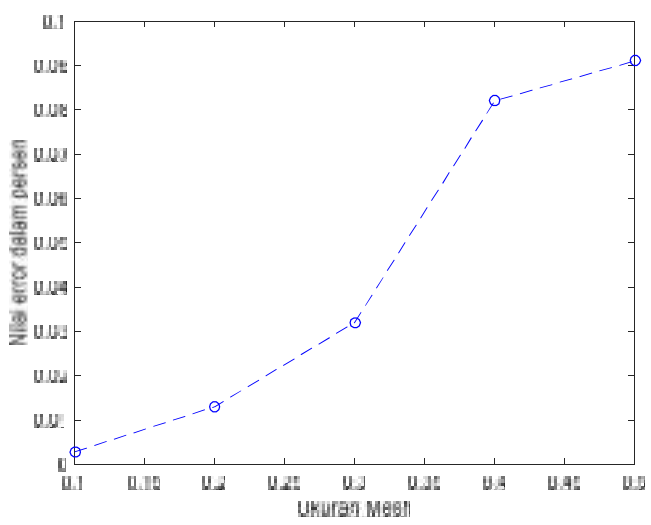

Gambar 2. Grafik ukuran mesh terhadap error.
Ukuran mesh menentukan tingkat akurasi taksiran numerik dengan analitik dimana ukuran elemen yang lebih lecil memberikan akurasi yang lebih tinggi dibandingkan dengan elemen yang lebih besar [4].

Nilai error terhadap variasi ukuran mesh ditunjukkan pada Gambar 2. grafik menunjukkan semakin kecil ukuran elemen semakin kecil pula nilai error yaitu mendekati 0 pada ukuran 0.1 .

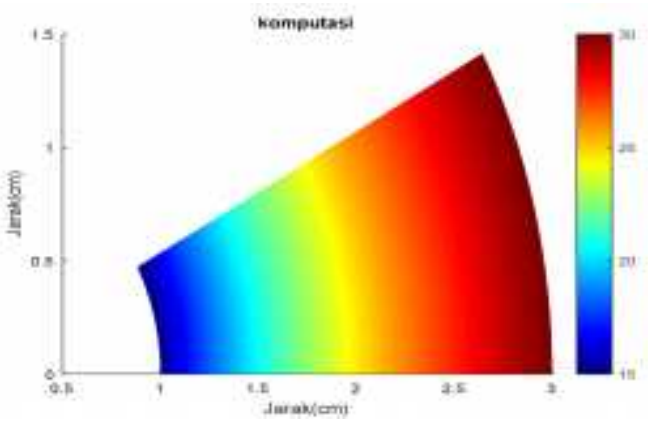

Gambar 3. Permodelan solusi potensial kecepatan dalam sumbu x-y.

Dari gambar 3 kita dapat menyimpulkan bahwa nilai solusi tidak berubah menurut sudut koordinat hanya bergantung pada nilai jari-jari saja. Artinya kecepatan yang muncul hanyalah kecepatan radial atau $v_{r}$ sementara nilai kecepatan tangensial $v_{U}=0$.

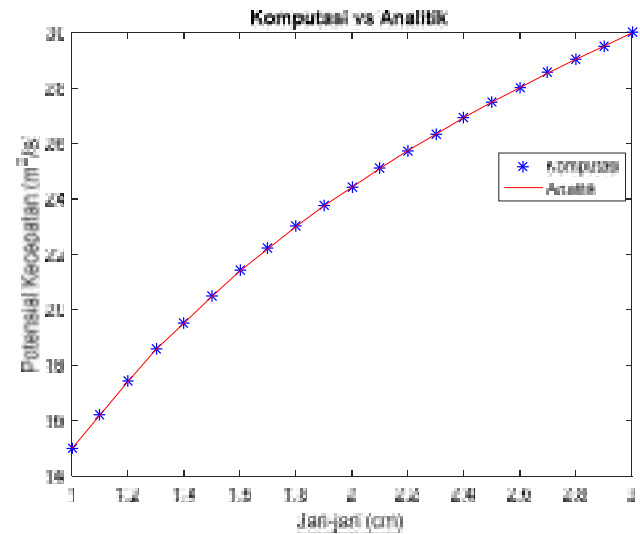

Gambar 4. Permodelan perhitungan analitik dan numerik

Perbandingan antara analitik dan numeric diatas diambil dari jarak $r=1 \mathrm{~cm}$ sampai $r=3 \mathrm{~cm}$ dengan sudut koordinatnya adalah sebesar $0^{\circ}$. Sudut koordinat ini tidak banyak 
berpengaruh karena solusi yang didapat adalah tidak dipengaruhi oleh sudut atau radial murni. Nilai potensial bertambah secara logaritmik yang sesuai dengan solusi analitik pada persamaan 7 .

$\varphi(r, \theta)=\varphi_{1}+\frac{\psi_{2}-\psi_{1}}{\operatorname{l1} \frac{b}{a}} \ln \frac{r}{a}$

Nilai rata-rata dari simulasi adalah sebesar $23.7288 \mathrm{~m}^{2} \mathrm{~s}^{-1}$ dan nilai rata-rata analitik adalah sebesar $23.7787 \mathrm{~m}^{2} \mathrm{~s}^{-1}$. Error yang didapat jika dinyatakan dalam persen adalah sekitar $2.9273 \times 10^{-4} \%$.

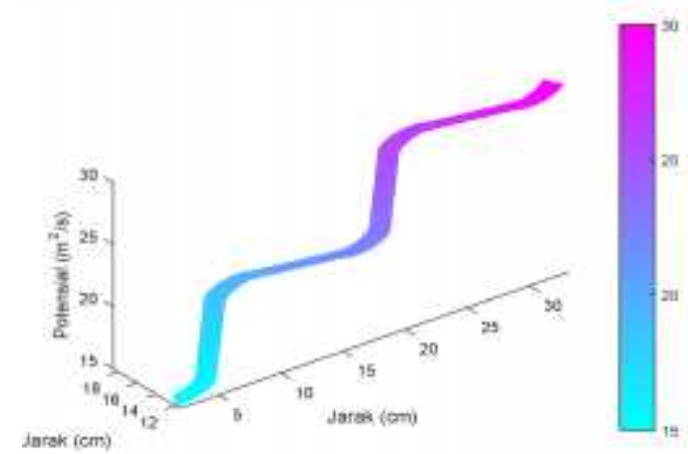

Gambar 5. Tampilan pemodelan potensial dari domain tidak teratur.

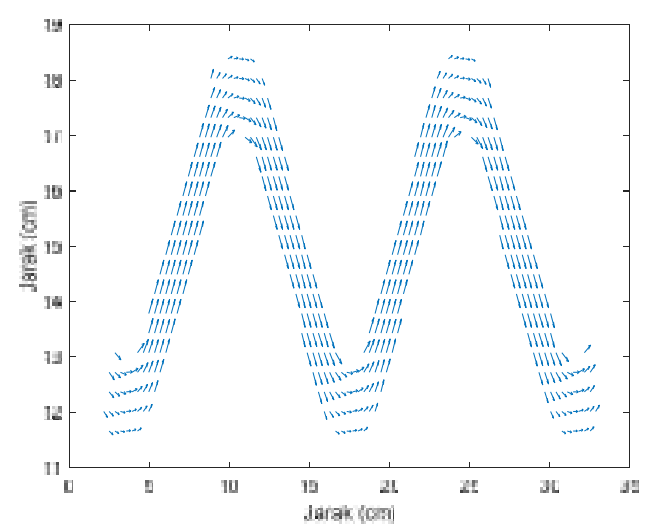

Gambar 6. Tampilan distribusi kecepatan

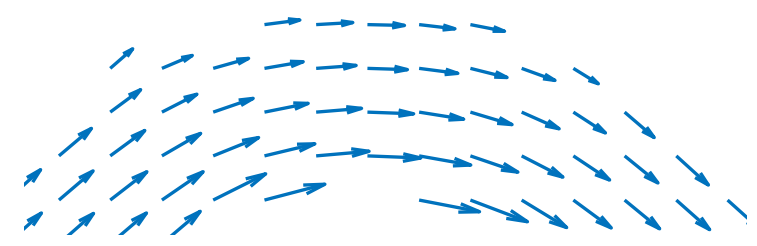

Gambar 7. Distribusi kecepatan pada lengkungan bagian atas.

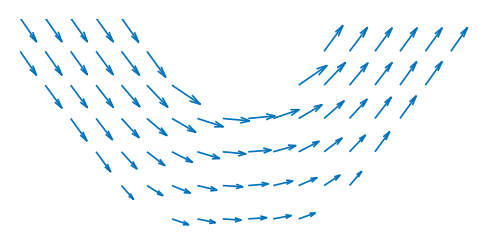

Gambar 8. Distribusi kecepatan pada lengkungan bagian bawah.

Aliran kecepatan pada segmen bagian lengkung atas berotasi searah dengan jarum jam sementara pada bagian segmen bagian lengkungan bagian atas berotasi berlawanan arah jarum jam. Hal yang menarik adalah arah aliran hanya berubah secara melingkar atau mengikuti lintasan. Dapat diindikasikan keceptan yang terjadi hanyalah kecepatan tangensial saja dan tidak terjadi kecepatan radial atau $v_{y}=0$. Jika ditarik garis secara radial tampak bahwa besar kecepatan berbanding terbalik terhadap jari-jari. Artinya semakin jauh fluida dari pusat kelengkungan semakin rendah kecepatan yang dihasilkan. Fenomena ini menyerupai vorteks bebas.

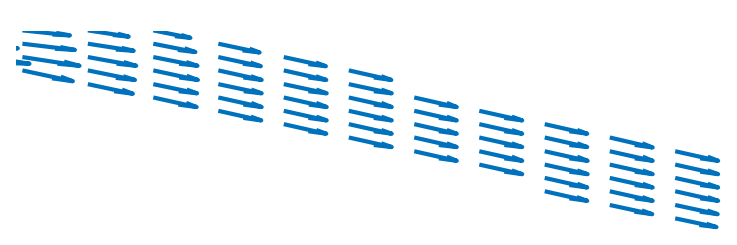

Gambar 9 Pemodelan kecepatan pada segmen saluran lurus.

Dari gambar 9 terlihat bahwa aliran yang terjadi adalah aliran seragam yang mengarah ke sudut $\alpha$ sembarang pada bidang lurus menuju sumbu y positif.

\section{KESIMPULAN}

Ukuran mesh berpengaruh terhadap error. Semakin kecil ukuran mesh semakin akurat hasil simulasi. Pada daerah lengkungan aliran fluida ideal cenderung berupa vorteks bebas yang disebabkan oleh gaya sentripental dari 
lintasan melingkar sementara pada bidang lurus aliran cenderung berupa aliran seragam. Nilai selisih analitik dan komputasi untuk model domain tidak teratur adalah 0.001 dan error yang dihasilkan adalah $2.83 \times 10^{-3} \%$ sehingga baik untuk memodelkan aliran fluida ideal.

\section{REFERENSI}

1. Kuntjoro, H, D., Pudiastuti, \& Saptarita. (2011). Studi literatur koreksi model matematis aliran di lengkung sungai. Jurnal Aplikasi, 1-14.
2. Munson, B. R., Young, D. F., \& Okiishi, T. H. (2003). Mekanika Fluida. Jakarta: Penerbit Erlangga.

3. Kosasih, P. B. (2012). Metode Elemen Hingga . Yogyakarta: Andi Yogyakarta.

4. Dutt, A. (2015). Effect of mesh size on finite element analysis of beam. SSRG International Journal of Mechanical Engineering, 8-10.

5. Mustain, M. (2011). Mekanika Fluida. Surabaya: ITS Press. 